Volume 7 Issue 2, June 2020

Nationally Accredited Journal,

Decree No. B/4130/E5/E5.2.1/2019

\title{
Legal Protection Against Substitute Notary in Semarang Based on Act No. 2 of 2014 Amendment Act No. 30 of 2004 concerning Notary
}

\author{
Setyawati ${ }^{1}$, Putri Nofita $\mathbf{S}^{2}$ and Fahrurroji Sidik ${ }^{3}$
}

Abstract. The purpose of this study are to: 1) to identify and analyze the implementation of the legal protection of Substitute Notary in Semarang based on Act No. 2 of 2014 amendments to the Act No. 30 Of 2004 on Notary. 2) to identify and analyze the constraints and solutions on the legal protection of Substitute Notary in Semarang based on Act No. 2 of 2014 amendments to the Act No. 30 Of 2004 on Notary.

Based on the results of data analysis concluded that: 1) the implementation of the legal protection of Substitute Notary in Semarang based on Act No. 2 of 2014 amendments to the Act No. 30 of 2004 concerning Notary, that the authority and obligation Substitute Notary has the same status as Notary Public. Substitute Notary Public Notary and is common in performing official duties stipulated by the Act. 2) Obstacles and solutions on the legal protection of Substitute Notary in Semarang based on Act No. 2 of 2014 amendments to the Act No. 30 of 2004 concerning Notary, Professional Notary protected by the Honorary Council of Notaries that served to protect the profession Notary not Notary personal, Notary Honorary Council oversees only ethical behavior Substitute Notary Public Notary and regulated in UUJN, Perkemenkumham and Notary Code of Ethics, and preferably Substitute Notary must always adheres to the rule of law that is UUJN, Perkemenkumham and Notary Code. If all rules are fulfilled, Substitute Notary will be free from claims filed her form.

Keywords: Legal Protection; Substitute Notar; UUJN.

\section{Introduction}

The Republic of Indonesia as a constitutional state based on Pancasila and the Constitution of the Republic of Indonesia of 1945 to ensure certainty, order and legal protection for every citizen. To ensure order and the legal protection required written evidence that is Authentic regarding deeds, agreements, stipulations and legal events made before a competent authority. ${ }^{4}$

In Act No. 2 of 2014 amendments to the Act No. 30 of 2004 concerning Notary (UUJN) stated that the notary is a General Authorities authorized to make Deed Authentic and have other authorities referred to in this Act or pursuant OF others. Communities in their activities are mostly related to the law and require that a Notary Law Service. Notary has the obligation to ensure the correctness of the Acts made. In Making Authentic Notarial Deed should be honest, fair and transparent in the Preparation of a Deed in order to guarantee all the parties directly involved.

Meaning Authentic Deeds have perfect strength of evidence can also be determined that those bound by the deed, all can not be proven, evidence to the contrary by a court

1 Lecturer, Faculty of Law, Sultan Agung Islamic University, Semarang email setyawatiham@gmail.com

${ }^{2}$ Student Master of Notary Program, Faculty of Law, Sultan Agung Islamic University, Semarang email putrinovita61@gmail.com

${ }^{3}$ Student of Master of Law Program, Faculty of Law, Universitas Islam Sultan Agung

${ }^{4}$ Luthfan M. Hadi Darus, 2017, Hukum Notariat Dan Tanggungjawab Jabatan Notaris,

Yogyakarta: UII Press p. 1. 
decision which has permanent legal force. ${ }^{5}$

Notary is a Public Official who has a great task and responsibility in carrying out His post for working professionals in the community regardless of any angle, therefore Notaries in terms of duties required the Fairness, Accuracy and Precautions. To avoid errors in the Making Authentic Deed, this profession requires a High Concentration and Physical Condition Good. Therefore every Notary has the right to take leave. This is in accordance with the provisions of Article 11 of the Act No. 2 of 2014 determines as follows:

- Notaries are appointed Compulsory State Officials Taking leave.

- Leave referred to in paragraph (1) shall be valid for Notary assume the position as Acting State; and

- Further provisions on leave Notary referred to in paragraph (1) is regulated by the Minister.

Notaries can apply for leave on condition that: 6

- Had undergone an initial term of 2 (two) years;

- Not meet the overall amount of time off later than twelve (12) years; and

- Appoint a Substitute Notary.

In UUJN Article 1, paragraph 3, was a Substitute Notary for the meantime to replace the appointed Notary being Leave, Sick, or Temporarily unable to run His position as a Notary Public.

Substitute notary merely temporary positions assumed by a particular who are qualified and limited time during the period of leave notary who replaced has not ended. During Substitute Notary of their duties, there is always the possibility of error in deed, so the Substitute Notary must be careful in terms of a deed of the parties, act and behave and maintain their health. The presence of Substitute Notary as Public Official is to meet the needs of the community will need a written evidence on every engagement they do in everyday life, in order to create legal certainty for all Indonesian citizens.

Legal Protection of the Notary and Notary Successor in carrying out its duties and authorities for the implementation of service functions and the achievement of legal certainty in providing services to the public, has been regulated and set forth in the Act itself, namely Law No. 2 of 2014 concerning Notary decisive " notary Public is Public officials authorized to Make Authentic Deed and have more authority as referred to in this Act or pursuant to other laws."7 Although authorized to make Deed Authentic but still must be careful in order not Making Authentic in the Deed Law.

Although the Legal Protection notary are arranged in UUJN, but the Legal Protection of the Substitute Notary unclear in UUJN, causing misunderstanding in terms of Substitute Notary Request Protection to whom. So that needs further research to determine what form of legal protection to be received by the Substitute Notary if doing Mistakes Making Authentic deed when carrying out their duties as Notary Substitute Causes Torts.

Based on the background mentioned above, the authors interested in taking title of the study as follows: "Legal Protection Against Substitute Notary in Semarang based on Act No. 2 of 2014 Amendment to Act No. 30 Of 2004 On Notary".

\section{Research methods}

\footnotetext{
${ }^{5}$ Habib Adjie 2011, Kebatalan dan Pembatalan Akta Notaris, Bandung: PT. Refika Aditama, p. 6. ${ }^{6}$ Regulation of the Minister of Justice and Human Rights of the Republic of Indonesia Number 19 Year 2019 on Conditions and Procedure for Appointment, Leave, Transfer, Termination and Extension of Term of Office Notary, Article 2.

${ }^{7}$ Article 1, Act No. 2 of 2014 Amendment Act No. 30 of 2004 concerning Notary
} 
Volume 7 Issue 2, June 2020

Nationally Accredited Journal,

Decree No. B/4130/E5/E5.2.1/2019

Method The approach used in this research is normative juridical. Normative juridical approach namely Legal Research conducted by examining the material library or a mere secondary data. ${ }^{8}$

Juridical approach is an approach that refers to the laws and regulations applicable legislation. ${ }^{9}$ Normative approach is the approach taken by way Researching library materials or secondary data on Principles of Law and the Case Study which in other words is often referred to as Legal Research Library. ${ }^{10}$ This research is Descriptive Analysis which presents the facts and analyze them systematically so that it can be easier to understand and concluded. Descriptive because the research is intended to provide a clear, detailed, and thorough on all matters relating to the Legal Protection of the Substitute Notary in Semarang. While the analysis was focused on the legal aspects that regulate concerning Notary and Legal Protection.

\section{Results and Discussion}

\subsection{Implementation of Legal Protection Against Substitute Notary in Semarang based on Act No. 2 of 2014 Amendment to Act No. 30 Of 2004 on Notary.}

Notary is a public official who is authorized to make an authentic deed and have more authority as referred to in this Act or pursuant to other laws. ${ }^{11}$

Authority of the Notary as a public official in charge of making the deed is authentic, including the authority in attribution because of the authority of Notary given by Law direct namely Act No. 2 of 2014 amendments to the Act No. 30 of 2004 concerning Notary Article 14 paragraph (1) stating Notary is authorized to make an authentic deed. In relation to the authority of the issues raised is if the Substitute Notary authorized by a Notary who is replaced in a deed authentic abused his power has resulted in the parties suffered losses and may cause the parties suffered losses and may result in deed authentic Notary Substitutes may be reversed,

Legislation governing the Notary Public and Substitute Notary is the same, namely Act No. 2 of 2014 Amendment to Act No. 30 Of 2004 regarding Notary hereinafter referred UUJN and Regulation of the Minister of Justice and Human Rights of the Republic of Indonesia Number 19 of 2019 on Conditions and Procedure for Appointment, Leave, Transfer, Termination and Extension of Term of Office Notary. Substitute Notary has the authority and responsibility are the same as notary.

With the above rules, to be a Substitute Notary can be known with certainty what conditions must be met and it is known authority and the obligation of a Substitute Notary. The existence of the Articles mentioned above can guarantee Notary practice although run by the Substitute Notary, and the regulation authority and obligation to prove that the Substitute Notary has the same status as the Notary. Protection of Substitute Notary in their duties should be properly and correctly according to legislation in force.

\footnotetext{
${ }^{8}$ Soerjono Soekanto and Sri Mamuji, 2001, Penelitian Hukum Normatif Suatu Tinjauan Singkat, Jakarta: King Grafindu Persada, p. 13.

${ }^{9}$ Roni Hanitjo Soemitro, 1982, Metodelogi Penelitian Hukum dan Jurimetri, Jakarta: Ghalia Indonesia, p. 20.

${ }^{10}$ Soerjono Soekanto and Sri Mamuji, Op. Cit, p. 18.

${ }^{11}$ Article 1, Act No. 2 of 2014 Amendment Act No. 30 of 2004 concerning Notary
} 
Notary Supervisory Council (MPD-MPW-MPP) and the Honorary Council of Notaries, hereinafter referred to MKN, there would be protective or provide protection against Substitute Notary who were convicted in performing his respective duties UUJN proven abuse.

According Ngadino, legal protection against Substitute Notary none of (MPD-MPW-MPPMKN), which protects supposed Honorary Council of Notaries, because the role of MKN less than optimal and duty MKN just watching the behavior of ethics Notary and Notary Substitute arranged in UUJN and Notary code. Legal protection as UUJN and candy. If the fight the criminal and civil law does not concern organizations and institutions, but if the violating UUJN, Candy and the Code, the penalty awarded by the MPD and MKN entitled. Sanctions can include oral reprimand or a written warning. In this case the task MPD is less clear.

If there is an unlawful act committed Substitute Notary no legal protection from MPD can only receive a report if the Substitute Notary examined, and they should hire a lawyer in private and MPD can not provide legal assistance and can not assist in court.

\subsection{Constraints and Solutions Implementation Legal Protection Against Substitute Notary in Semarang based on Act No. 2 of 2014 Amendment to Act No. 30 Of 2004 on Notary.}

Notary is a public official in carrying out his profession providing services to the public under applicable regulations and sticking to ethical codes notary office. Notary has the obligation to guarantee the truth of the deed made. In the manufacture of authentic Notary deed to be honest, fair and transparent in the preparation of a deed in order to guarantee all the parties directly involved. Substitute Notary and have the authority set out in UUJN and other legislation.

Privileges Notaries in UUJN is, Notary authorized to make the deed authentic about all manufacture, agreement, and the determination required by legislation and an interest to be stated in the certificate is authentic, guaranteeing the creation date of the deed, saving certificates, give, copy, and official copies, all of it along a deed that is not also assigned or excluded to other officials or any other person specified by the Act. ${ }^{12}$

In the exercise of authority, a notary and Notary Substitute required to determine the extent to which limit their authority. In addition to the authority that they have, Notary also has obligations to which they must in the execution of their office and the prohibition should not do that if these three things are violated, the Notary concerned shall obtain sanction in accordance with the provisions set out in Law of Notary ( UUJN).

Notary is a privileged position, resulting in the execution of their duties should be fostered, supervised by three (3) different institutions, namely: ${ }^{13}$

- Notary Supervisory Council (MPN), Article 67, paragraph 2 UUJN

- Notary Honorary Council (MKN), Article 66 A UUJN

- Notary Honorary Council (NSC), Article 10, paragraph 12 Statutes THIS

Substitute Notary often accused of participating assist committed a crime to provide false information into the notary deed. This has led to confusion, whether intentional Substitute Notary together the parties making a deliberate deed from the beginning to having committed a crime. Substitute Notary should not be biased to one party to the deed Authentic, because it can cause losses in one party so that it is an unlawful act.

\footnotetext{
12 Article 15 (2), Law No. 2 of 2014 Amendment Act No. 30 of 2004 concerning Notary

13 Seminar materials, 2018, Permasalahan Hukum Apa Yang Akan Terjadi di Dunia Notaris di

Tahun 2018, Semarang : Pengda Kota Semarang, p. 1
} 
Volume 7 Issue 2, June 2020

Nationally Accredited Journal,

Decree No. B/4130/E5/E5.2.1/2019

Substitute Notary protection solutions that are not entangled law, preferably Substitute Notary must always grounded in the rules of applicable law, namely UUJN, Perkemenkumham and Notary Code. If all rules are fulfilled, Substitute Notary will be free from claims filed her form.

\section{Closing}

\subsection{Conclusion}

Based on the research results can be concluded as follows:

- Implementation of Legal Protection Against Substitute Notary in Semarang based on Act No. 2 of 2014 Amendment Act No. 30 of 2004 concerning Notary, legislation governing Substitute Notary of Act No. 2 of 2014 amendments to the Act of No. 30 of 2004 concerning Notary and Regulation of the Minister of Justice and Human Rights of the Republic of Indonesia Number 19 Of 2019 About Terms and Procedure for Appointment, Leave, Transfer, Termination and Extension of Term of Office Notary. With the rules above, to be knowable Substitute Notary authority and the obligation of a Substitute Notary. Their UUJN and Regulation of the Minister of Justice and Human Rights of the Republic of Indonesia Number 19 Of 2019 About Terms and Procedure for Appointment, Leave, Transfer, Termination and Extension of the abovementioned period Notary can guarantee Notary practice although run by the Substitute Notary. Clauses in legislation proves that the authority and obligation Substitute Notary has the same status as Notary Public and Substitute Notary is a public official in performing their duties stipulated by the Act.

- Constraints and solutions Implementation of Legal Protection Against Substitute Notary in Semarang Based on Act No. 2 of 2014 Amendment Act No. 30 of 2004 concerning Notary, Professional Notary protected by the Honorary Council of Notaries that served to protect the profession Notary not personal Notary, preferably Substitute Notary must always grounded in the rules that apply that UUJN, Perkemenkumham and Notary Code. If all rules are fulfilled, Substitute Notary will be free from claims filed her form.

\subsection{Suggestion}

- In connection with the implementation of legal protection against Substitute Notary, should be clarified concerning the legal protection so that no confusion when caught in legal problems, Substitute Notary can be guided by the legislation in force.

- In connection with the constraints and solutions on the legal protection of Substitute Notary, should the role of the MPD, MPW, MPP, MKN more optimized again in providing legal protection of the Notary and Notary Substitute so that there are no obstacles in the legal process in court and the State should provide protection adequate law to the Notary and Notary Substitute and reinforce the duties and functions of the MPD, MPW, MPP, and MKN.

\section{References}

[1] Habib Adjie 2011, Kebatalan dan Pembatalan Akta Notaris, Bandung: PT. Refika Aditama

[2] Seminar materials, 2018, Permasalahan Hukum Apa Yang Akan Terjadi di Dunia Notaris di Tahun 2018, Semarang : Pengda Kota Semarang 
eISSN : 2581-2114, pISSN: 2406-9426

[3] Luthfan M. Hadi Darus, 2017, Hukum Notariat Dan Tanggung jawab Jabatan Notaris, Yogyakarta: UII Press

[4] Regulation of the Minister of Justice and Human Rights of the Republic of Indonesia Number 19 of 2019 on Conditions and Procedure for Appointment, Leave, Transfer, Termination and Extension of Term of Office Notary

[5] Roni Hanitjo Soemitro, 1982, Metodelogi Penelitian Hukum dan Jurimetri, Jakarta: Ghalia Indonesia

[6] Soerjono Soekanto and Sri Mamuji, 2001, Penelitian Hukum Normatif Suatu Tinjauan Singkat, Jakarta: King Grafindu Persada

[7] Act No. 2 of 2014 Amendment Act No. 30 of 2004 concerning Notary 